\title{
From Compliance With Environmental Regulations To Pursuit Of Environmental- Based Competitive Advantages: Mediators Of The Relationship In A SME Context
}

Karen Delchet-Cochet, ISC Paris Business School, France Linh-Chi Vo, Ecole de Management de Normandie, France Hakim Akeb, ISC Paris Business School, France

\begin{abstract}
Despite the huge amount of work written about environmental practices of SMEs, what continues in the debate is the relationship between their two motivations for environmental protection: the push motivation of environmental regulation compliance and the pull motivation of pursuing competitive advantages based on the environmental protection agenda in a win-win logic. Some scholars state that environmental regulation compliance motivates SMEs to pursue opportunities that they would miss otherwise, while others claim that the conformity to regulations results in mere compliance behavior. Thus, we contribute to the literature by probing the intervening variables to uncover when and how SMEs move from a push to a pull motivation. Within the scope of our study, we consider environmental regulations that are voluntary-oriented; we also focus on the pursuit of competitiveness that is based on the development of environmental-friendly products/services. The mediators that we examine include: market expansion, monitoring of business activities, innovative capacity, and adoption of environmental behavior of suppliers. We conduct our investigation among 161 French SMEs in 2011.
\end{abstract}

Keywords: SME; Mediator; Environmental Compliance; Environmental-Based Competitiveness

\section{INTRODUCTION}

ver the past few years, the ground-swell support from different stakeholders for environmental protection has resulted in increasingly willingness of companies to reduce the environmental impacts of their business activities. In this context, small and medium enterprises (SMEs) start contributing to the endeavor of protecting the environment and step up their environmental activities accordingly. In the academia, the growing recognition that SMEs have a significant aggregate influence on the environment (Gadenne et al., 2009; Tilley, 2000) has fueled research into environmental management practices among smaller firms (e.g., Fuller and Tian, 2006; Williamson et al., 2006).

Despite the huge amount of work written about environmental practices of SMEs, what continues in the debate is the relationship between their two motivations for environmental protection, which have been described as two ends of a continuum, reflecting reactive and proactive behavior (Bianchi and Noci, 1998; Torugsa, O'Donohue and Hecker, 2013) or push and pull motivations (Revell, Stokes, and Chen, 2010). The first motivation is environmental regulation compliance, which implies the need for long-term survival of the firm and the license to operate, and is linked to behaviors aimed at avoiding the negative consequences of non-compliance. The second one is the pursuit of competitive advantages based on an environmental protection agenda in a win-win logic (Porter and van der Linde, 1995). There have been conflicting viewpoints and evidences concerning whether the compliance with environmental regulations motivates SMEs to seek for competitive advantages by relying on environmental activities. Some scholars state that environmental regulation compliance motivates SMEs to pursue opportunities 
that they would miss otherwise (cf. Ambec et al., 2013). By contrast, it is argued that the conformity to regulations results in mere compliance behavior among SMEs. Environmental regulations have been found unable to convince SME owner-managers of the 'business case for sustainability' (Worthington and Patton, 2005).

The debate is inconclusive because the relationship between environmental regulation compliance and the pursuit of environmental-based competitiveness is complex and indirect in a SME context. It is important to probe the intervening variables to uncover when and how SMEs move from a reactive behavior to a proactive one. Thus, the objective of this article is to contribute to the literature by examining the mediators of this relationship through an investigation in the context of French SMEs in 2011. Within the scope of our study, we consider environmental regulations that are voluntary-oriented; we also focus on the pursuit of competitiveness that is based on the development of environmental-friendly products/services. Our study thereby contributes to the literature by shedding light on when and how compliance with voluntary environmental regulation motivates SMEs to develop environmental-friendly products/services for competitive advantages.

Our paper is organized as following. We will first review the controversy regarding the relationship between environmental regulation compliance and the pursuit of environmental-based competitiveness in a SME context. We then discuss the reasons why the scope of our study is limited to environmental regulations of voluntary nature and competitiveness based on the development of environmental-friendly products/services. We present our theoretical framework in the following section. Our hypotheses are thereby developed. Our methodology section and findings follow. Our paper ends with a discussion of our findings and a conclusion.

\section{FROM COMPLIANCE WITH ENVIRONMENTAL REGULATIONS TO THE PURSUIT OF ENVIRONMENTAL-BASED COMPETITIVE ADVANTAGES: THE CONTROVERSY}

Empirical studies find that SMEs are generally positive about the potential role of regulation in encouraging environmental reform within the SME sector. They agree that there should be more regulations to control the environmental impacts of all businesses (Revell, Stokes, and Chen, 2010), to establish a minimum acceptable standard of behavior, and to provide a source of external pressure that has arguably been lacking to date (Tilley, 2000). However, the picture concerning the relationship between environmental regulation compliance and the development of environmental-friendly products/services for competitive advantages in the context of SMEs is inconsistent in the literature.

On the one hand, it has been argued that environmental regulations motivate SMEs to develop environmental protection agenda for competitive advantages. According to the behavioral economics perspective, the rationality of SMEs is driven by their owner-managers. They lack time and knowledge about corporate social responsibility (CSR) (Lepoutre and Heene, 2006), perceive that CSR is an issue that only pertains to larger firms (Vives, 2006; Sweeney, 2007), and often follow a short-term approach of strategy due to survival pressure and financial resource limitations (Sweeney, 2007). They miss environmental-based investment opportunities because they do not see immediate financial gains. By requiring such investments, environmental regulations help SME managers overcome this self-control problem, which enhances firm profits. The behavioral economics perspective justifies the existence of 'win-win' opportunities based on the notion that regulation requires certain behaviors that are ultimately profit maximizing for the firm but might not otherwise be chosen by the manager (Ambec et al., 2013).

Empirical studies have found evidence showing a positive relationship between environmental regulation motive and environmental-based competitiveness motive of SMEs. For example, from an investigation of four SMEs, Noci and Verganti (1999) found that the companies attempted to create green product innovation when the product and process environmental regulations were introduced. Moreover, it has been acknowledged that the role of government in monitoring and regulating product is to ensure that consumers who want environmental-friendly products will be able to purchase them rather than buying products falsely claiming to be green (Rege, 2000). This makes business owners increasingly positive about the business case for sustainability and willing to accept the idea that future economic growth is predicated on long-term environmental protection, and that environmental solutions may also result in business opportunities (Revell, Stokes, and Chen, 2010). 
On the other hand, it is argued that regulation appears to be one of the main drivers of environmental management amongst SMEs, but outcomes of this includes the observation that environmental management is often reactive among SMEs._ Because many certification systems are difficult to administrate and organize for small businesses, institutional pressure often leads to environmental activities of mere compliance, which in turn have been found to have an insignificant impact on a firm's business activities (Darnall et al., 2008). Support for this view is provided by studies of the impact of regulation upon the behavior of SMEs, which suggest that regulation does not result in behavior that goes beyond compliance in the form of modernization and cultural change (Williamson et al., 2006; Worthington and Patton, 2005). Environmental regulations have been found unable to motivate SME ownermanagers to pursue competitive advantages. The types of environmental practices that produce a cost reduction effect, as well as being a positive change in environmental terms, are those that tend to be most consistently applied by SME owner-managers (Ilomaki and Melanen, 2001). Similarly, in a study of manufacturing SMEs, Williamson et al. (2006) discovered that it is the cost reduction element of the behavior change that is motivating for them, and the environmental benefit is simply a positive byproduct. These studies indicate that 'win-win' outcomes from environmental management have yet to materialize for many SMEs (Revell, Stokes, and Chen, 2010).

\section{SCOPE OF THE STUDY}

During the last two decades, regulations for environmental protection have followed one another. Environmental regulations can be broadly classified into two major categories: voluntary and compulsory (Gendron, 2000; Karlfeld and Depuech, 2008). Research needs to make a distinction between them because regulations of different natures have different impacts on the environmental activities of the firm (Iraldo et. al., 2011). Within the scope of this study, we look at environmental regulations that are voluntary-oriented. This is because the voluntary approach in environmental regulations has been emphasized throughout the world, from the European Union to the United States (Delbard, 2008). It is, however, important to note that voluntary regulations imply both voluntary and binding nature (Klarsfeld and Delpuech, 2008).

The pursuit of competitiveness by relying on an environmental protection agenda includes three dimensions: innovation in products and services, serving unserved markets, and building new business models (Grayson and Hodges, 2004). We focus on the dimension of innovation in products and services, which implies that the SME attempts to develop products/services that fulfill traditional criteria as well as environmental requirements, thereby moving ahead of competitors. This is because products/services and their consumption have more significant impact on environmental degradation compared to the other two dimensions (European Commission, 2010; European Commission, 2003). Moreover, among these dimensions, understanding green products/services development has become a strategic priority for theory and practice (Dangelico and Pujari, 2010). The interest in developing environmental-friendly products/services has being growing exponentially (cf. Berchicci and Bodewes, 2005).

\section{FROM COMPLIANCE WITH VOLUNTARY-BASED ENVIRONMENTAL REGULATIONS TO DEVELOPMENT OF ENVIRONMENTAL-FRIENDLY PRODUCTS/SERVICES FOR COMPETITIVE ADVANTAGES: THE MEDIATORS}

As presented above, it is inconclusive whether SMEs go beyond mere compliance to seek for competitive advantages by relying on environmental agenda. This controversy remains because intervening, or mediating, variables between regulation compliance and the pursuit of environmental-based competitiveness have not been examined. Within the scope of this study, we aim at examining the relationship between compliance with voluntarybased environmental regulations and development of environmental-friendly products/services for competitiveness. Four factors are predicted to mediate this relationship: market expansion, monitoring of business activities, innovation capacity, and adoption of environmental behavior of suppliers. This section presents our hypotheses regarding these mediators.

\section{First Mediator: Market Expansion}

It has been suggested that SMEs' approach to responsible practice is strongly linked to the theory of social capital (Spence et al., 2003; Perrini, 2006). This theory puts the concept of social capital at the core of the 
relationship between companies and their environment. Social capital refers to the connections among individuals/social networks and the norms of trustworthiness, mutual obligation, reciprocity, and trust that arise from them (Adler and Kwon, 2002; Putnam, 1995, 2000). As corporate and individual consumers are increasingly aware of environmental issues and start placing pressure upon SMEs to adopt measures of environmental protection (cf. Ciliberti, Pontrandolfo, and Scozzi, 2008), the compliance with environmental regulations, albeit voluntary in nature, helps the SMEs increase their social capital through better acceptance of the community and customers. Increased social capital, in turn, becomes a tool for them to deal with their business issues (Spence et al., 2003).

One business issue, which can be addressed by social capital brought by environmental behavior, is the expansion of customer base, as shown in the case study conducted by Lamberti and Noci (2012). Compliance with environmental regulations makes SMEs eligible to serve customers, who are environmental-friendly and include CSR criteria in their purchasing decisions. They can go as far as participating in the activities of environmentally proactive corporate customers such as new product development (Geffen and Rothenberg, 2000; Pujari et al., 2003). Indeed, SMEs are making stronger voluntary efforts to comply with environmental requirements, in accordance with their customers' expectations (cf. Baden, Harwood, and Woodcard, 2009). The desire to improve relations with clients is often cited by SMEs as one of the most common motivations to engage in environmental responsibility (cf. Vives, 2006).

On the other hand, according to stakeholder theory (Freeman, 1984), customers are an important group of stakeholders. The pressures that they place on firms are a key influence on the design of features that firms build into, or omit from, their products. Consumer preference is reported to be instrumental in driving organizations towards green product development (Albino et al., 2009; Iles, 2008) and change in corporate environmental behavior (Lamming and Hampson, 1996). Thus, SMEs that seek to expand their market base are more likely to produce products that have features that result in consumer-perceived environmental benefits. Customers can manifest their power through collective market pressure (Tyran and Eneglmann, 2005). Empirically, a host of 'willingness to pay' studies suggests that consumers are willing to pay more for environmentally friendly products (Ottman, 1998; Rowlands et al., 2003; Shrum et al., 1995). Furthermore, consumer willingness to pay more for environment friendly products has been shown to hold true across racial (Newell and Green, 1997) and national differences (Bhate, 2002).

With these arguments, we predict that voluntary compliance with environmental regulations enables SMEs to expand their market base, which in turn motivates them to develop environmental-friendly products/services for competitiveness.

Hypothesis 1: Market expansion mediates the relationship between SMEs' voluntary regulation compliance and their pursuit of competitiveness by developing environmental-friendly products/services.

\section{Second Mediator: Monitoring Of Business Activities}

When SMEs follow voluntarily environmental regulations, they are motivated to monitor their business activities accordingly. This is because the complexity of environmental practices presents more difficulties to the SMEs than to large enterprises (Tilley, 1999). Potential conflict can arise between environmental goals and production and survival pressures (Petts, 2000). The implementation of environmental agenda also requires substantial resources and sophisticated management expertise (Sharma and Vredenburg, 1998). SMEs monitor their activities to make sure environmental compliance does not mitigate against their business performance. Empirical studies show that SMEs are able to formalize environmental engagement along their business principles such as vision, mission, and value (Perrini and Minoja, 2008). Their business principles and environmental activities coexist not as a 'juxtaposition', but a correlation. Ethical commitments encourage SMEs to have a more strategic approach to CSR (Lamberti and Noci, 2012).

When business activities are monitored, the SMEs are more inclined to develop environmental-friendly products/services. Based on the concept of frames and their effect on decision-making processes, which have been extensively explored in the psychology field (Buechler, 2000; Gray, 2003; Roth and Sheppard, 1995), frames provide a 'perspective or viewpoint that people use when they gather information and solve problems' and the 
framing process and cause people to exhibit certain types of behavior while ignoring or avoiding others. As business activities are monitored in the context of environmental compliance, the frames of the owners of SMEs set environmental issues as one factor in their decision making process. Thus, developing environmental-friendly products/services is taken into consideration in their strategic decisions.

We argue that voluntary environmental regulation compliance drives SMEs to monitor their business activities, which in turn motivate them to create competitive advantage by developing environmental-friendly products and/or services.

Hypothesis 2: Monitoring of business activities mediates the relationship between SMEs' voluntary regulation compliance and their pursuit of competitiveness by developing environmental-friendly products/services.

\section{Third Mediator: Innovative Capacity}

Voluntary compliance with environmental regulations contributes to developing the innovative capacity of SMEs. In the reflexive models of environmental management, scholars argue that mounting pressure to protect the environment leads to ecological innovation. According to these models, the way to reduce environmental problems is further modernization such as innovations, even though (ironically) modernization causes the problem in the first place (Brand 2010; Mol 2000). Although SMEs have been described as lacking resources devoted to responsible activities, they can develop innovative capacity thanks to assistance from third-party organizations, which may provide a necessary external impulse, motivation, and advice to initiate or continue with environmental protection (Gombault and Versteege, 1999). Literature recognizes various types of third-party organizations such as governments and local authorities, NGOs, universities, and consultancies (Afsarmanesh and Camarinha-Matos, 2009; del Brio and Junquera, 2003; Howells, 2006; Massa and Testa, 2008; Zeng et al., 2010). These parties help SMEs gain access to and exchange relevant ecology and sustainability-related information (Spence et al., 2003), which enables them to enhance their innovative capacity (Klewitz, Zeyen, and Hansen, 2012).

Besides, companies with an innovative ability are motivated to create competitive advantage by developing innovative products and services with CSR credentials (Jenkins, 2009). According to the theory of planned behavior (Sharma and Sharma, 2011; Ajzen, 1991), attitudes and beliefs about the behavior - especially with respect to possible positive and negative consequences of the behavior, and related perceived values of those outcomes - have a positive influence on the adoption decision. In particular, attitudes toward 'newness' or innovation more generally may spill over to attitudes with respect to adopting new environmental management practices. Thus, innovative SMEs are predicted to be more likely to engage in development of environmental products and/or services because they understand environmental management practices as another source of ideas for innovation and in particular for sustainable product development (Crowe and Brennan, 2007; Berchicci and Bodewes, 2005). In fact, empirical studies have shown numerous examples of innovation in SMEs by developing products and services that incorporated social and/or environmental benefits (Jenkins, 2009).

In addition, according to the resource-based view of the firm that organizational capabilities derive from a firm's resources (or characteristics) provide the foundation for successful strategy formulation (Barney 1991; Wernerfelt 1984), the characteristic creativeness and innovativeness of SMEs enable them to forecast external opportunities and threats and be proactive in taking advantage of new niche markets for products and services that have added value in the form of environmental benefits (Jenkins 2006). Empirical research has confirmed that those companies acting responsibly with respect to sustainability also innovate with respect to their products, technologies, processes and overall strategies (Nidumolu et al., 2009).

These arguments lead to our hypothesis that voluntary environmental compliance helps SMEs develop environmental innovative capacity, which in turn enables them to create competitive advantage by developing environmental-friendly products/services.

Hypothesis 3: Innovative capacity mediates the relationship between SMEs' voluntary regulation compliance and their pursuit of competitiveness by developing environmental-friendly products/services. 


\section{Fourth Mediator: Adoption Of Environmental Behavior Of Suppliers}

When SMEs adopt voluntarily regulated environmental practice, they encourage their suppliers to become more environmental-oriented. This is because companies have to manage their supplier involvement if they want to reduce or minimize the environmental impacts of their activities (Lee and Kim, 2011). It has been argued that as buyers, SMEs can exert pressure through the supply chain (Jenkins, 2006) despite the absence of power and resources. The supply chain activities of SMEs will have to be more imaginative in order to convince partners to adopt an environmentally responsible behavior. Different strategies are adopted to this end. Trust offers the SME an alternative for managing inter-firm relationships with suppliers (Ayuso, Roca and Colome, 2013), as the literature on SMEs suggests that they use social factors in commercial relationships (Morrissey and Pittaway, 2006). SMEs can also show a well-known willingness to use the sanction of switching suppliers for CSR reasons, and they can also identify and share cost-savings and income-generation from CSR with suppliers (European Multi-Stakeholder Forum, 2004). Championing CSR is another alternative to foster environmental responsibility along the supply chain (Jenkins, 2006).

When their suppliers are environmentally responsible, SMEs are motivated to create competitive advantage by developing environmental-friendly products/services. Increasing numbers of scholars have recognized the interconnections between green issues and supply chains. Different terms, such as green supply chain, green supply chain management, environmental supply chain management, and green supply chain practices (Lee and Kim, 2011), have been used to discuss the role of environmentally sensitive suppliers in the development of environmental-friendly products and services. It has been acknowledged that a close relationship between each member in a supply chain accelerates the creation of new opportunities for better economic and environmental performance (Lee, 2009). The model for the development of environmental-friendly products in the context of SMEs, which was put forth by Noci and Verganti (1999), include the environmental behavior of suppliers as a crucial component. Economic success in the long term can be achieved by integrating suppliers in the early stages of product development planning and design, which cover over $80 \%$ of the total costs of the product life cycle and determine the environmental impact of products (Tischner et al., 2001).

Thus, we hypothesize that voluntary regulation compliance of SMEs make their suppliers adopt an environmentally responsible behavior, which in turn enables SMEs to create competitive advantage by developing environmental-friendly products/services.

Hypothesis 4: The adoption of environmental behavior of suppliers mediates the relationship between SMEs' voluntary regulation compliance and their pursuit of competitiveness by developing environmental-friendly products/services.

Our hypotheses are summarized and represented in Figure 1 below. 


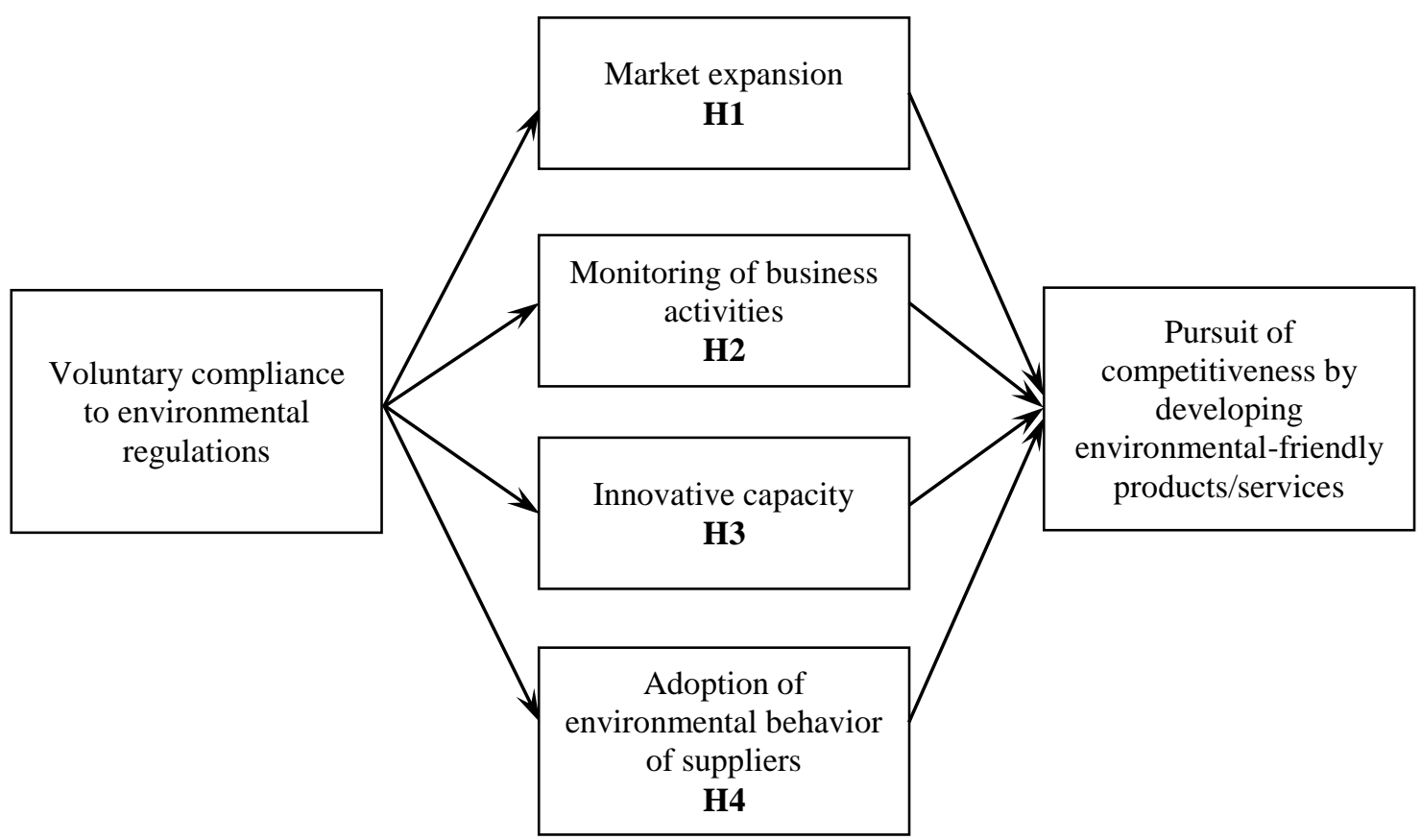

Figure 1. Theoretical Framework

\section{METHODOLOGY}

\section{The French Context}

France provides an interesting context for our investigation because French SMEs are embedded in a particular institutional environment. The corporate social responsibility (CSR) agenda of French companies tends to incline toward labor protection. Whereas in English the term social includes society, in France it is focused internally on labor-related issues, rather than on external stakeholders. France is well known for its strong protection of labor right. The influence from French labor law, the trade unions, and the long-standing mandatory social report has led to thorough application of the social side of CSR as far as employee treatment and rights are concerned (Antal and Sobczak, 2007).

In terms of environmental issues, environmental law has become quite developed in France over the past few years. The government is active in intervening the environmental practices of companies. The 'Grenelle law' and its article 225, being introduced in 2009 and 2010 (www.legrenelle-environnement.gouv.fr) and continuing the law of 'New Economic Regulations' of 2002, puts pressure on enterprises in terms of key ecological and sustainable development policies and extends the reporting obligation to companies having more than 500 employees and 100 million euros turnover. Since 2003, the national strategy of sustainable development underlines the importance of assisting SMEs in adopting environmental practices. However, the focus on environmental aspect continues to be considered as more reactive in France in comparison with other European countries such as Germany and countries in Northern Europe (Hudson and Roloff, 2010).

\section{Sample And Data Collection}

The sample for this study is drawn from a panel of about 1200 French SMEs that are members of the Center for Young Entrepreneurs, a French association of SMEs. In collaboration with the Center, we conducted an online survey in 2011 about their CSR practices. 22 questions were used to measure the variables of our investigation (see Appendix 1 for exact wording of the questions). For each of the questions, there are four levels of answer: no commitment or minimum commitments required by the law (score 1), active plan and actions to be made in the short term (score 2), active plan and actions (score 3), and aspirations for ideals (score 4). These levels of answer were 
inspired from the model of Enderle and Tavis (1998) and Enderle (2004). After missing data are taken into account, the final sample used for our analysis includes 161 cases.

\section{Measures}

Details about the items used in the study are provided in this section.

- Independent variable: voluntary compliance to environmental regulations of voluntary nature is measured by the mean score of four items, which include carbon release, environmental norms and standards, resources for environmental protection activities and objectives of environmental impact reduction (Cronbach's $\alpha=0.83$ ).

- Dependent variable: pursuit of competitiveness by developing environmental-friendly products/services is measured by the mean score of two items, which include analysis of the environmental impact of existing products/services and development of environmental-friendly products/services (Cronbach's $\alpha=0.62$ ).

- $\quad$ Mediating variables:

- Market expansion is measured by the mean score of two items, which include analysis of customer expectation and presentation of products/services to future customers (Cronbach's $\alpha=0.53$ ).

- Adoption of environmental behavior of suppliers is measured by the mean score of three items, which include choice of suppliers, environmental criteria imposed on suppliers, and implication of suppliers in environmental projects (Cronbach's $\alpha=0.59$ ).

- Innovative capacity is measured by the mean score of three items, which include new idea cultivation, new idea selection and measurement of innovative performance (Cronbach's $\alpha=$ $0.63)$.

- Monitoring of business activities is measured by the mean score of three items, which include growth monitoring, strategic plan, and market watch (Cronbach's $\alpha=0.65$ ).

- $\quad$ Control variables include two factors: firm size and tangibility of sector.

- $\quad$ Firm size is a control variable because it dominates the environmental social science literature as an explanation for differences in environmental practices of the firm (Uhlaner et al., 2012) and its supply chain (Ayuso, Roca and Colome, 2013). It is measured as the number of people employed by the firm in 2011. We then recode this variable as an ordinal variable according to our size categories. Companies having less than 10 employees were coded as 1, from 10 to 49 employees as 2 , and from 50 to 250 as 3 .

- Tangibility of sector is a control variable because it has been shown to motivate the level of engagement in environmental practices of SMEs (e.g. Uhlaner et al., 2012; Jenkins, 2006) and their supply chain members (Maloni and Brown, 2006). To measure tangibility of sector, the sample firms are first grouped into nine sectors, including manufacturing, construction, transport and communication, retail and repair, catering and hospitality, agriculture, financial services, business services, and other services (Uhlaner et al., 2010). The variable is then recoded as an ordinal variable according to the degree of tangibility, as proposed by Brand and Dam (2009). Firms in financial services, business services and other service sectors are coded as intangible services (1). Firms in transport and communication, retail and repair, and catering and hospitality are coded as tangible services (2). Firms in manufacturing, construction and agriculture are coded as tangible products (3).

\section{Statistical Method}

The method used for analysis was ordinary least squares (OLS) regression. To test the mediating role of market expansion, adoption of environmental behavior of suppliers, innovative capacity, and monitoring of business activities, we adhered to the procedure outlined by Baron and Kenny (1986). Testing for mediation consists of four critical steps:

- $\quad$ Step 1: the independent variable must influence the dependent variable.

- $\quad$ Step 2: the independent variable must influence the presumed mediator.

- $\quad$ Step 3: the mediator must influence the dependent variable while controlling for the independent variable. 
- $\quad$ Step 4: a previously significant relationship between the independent and dependent variables must be reduced in the presence of the mediator.

\section{RESULTS}

\section{Descriptive Statistics}

Table 1 reports the bivariate Pearson-correlation coefficients between the variables included in the study. These statistics provide preliminary answers to our research question.

The pattern of correlation coefficients listed in the table shows that the pursuit of competitiveness by developing environmental-friendly products/services is correlated to voluntary environmental regulation compliance, as well as the mediating variables, including market expansion, adoption of environmental behavior of suppliers, innovative capacity, and monitoring of business activities. Voluntary environmental compliance is also correlated to these mediating variables. The largest positive correlation is observed between the pursuit of competitiveness by developing environmental-friendly products/service and voluntary environmental regulation compliance, where $\mathrm{r}=0.4835(p<0.05)$. Multicollinearity diagnostics did not reveal any problems in the regressions (results not shown). These results provide supports to the first three steps in the procedure of testing for mediation outlined above.

Table 1. Bivariate Correlations Between Variables

\begin{tabular}{|c|c|c|c|c|c|c|c|c|}
\hline Variable & 1 & 2 & 3 & 4 & 5 & 6 & 7 & 8 \\
\hline $\begin{array}{l}\text { 1. Pursuit of competitiveness by } \\
\text { developing environmental-friendly } \\
\text { products/services }\end{array}$ & 1.0000 & & & & & & & \\
\hline 2. Firm size & $\begin{array}{l}0.2124^{*} \\
0.0068\end{array}$ & 1.0000 & & & & & & \\
\hline 3. Sector tangibility & $\begin{array}{l}0.1801 * \\
0.0223\end{array}$ & $\begin{array}{l}0.2180 * \\
0.0055\end{array}$ & 1.0000 & & & & & \\
\hline $\begin{array}{l}\text { 4. Voluntary compliance to } \\
\text { environmental regulations }\end{array}$ & $\begin{array}{l}\mathbf{0 . 4 8 3 5 *} \\
0.0000\end{array}$ & $\begin{array}{l}0.2930 * \\
0.0002 \\
\end{array}$ & $\begin{array}{l}-0.0277 \\
0.7270 \\
\end{array}$ & 1.0000 & & & & \\
\hline 5. Market expansion & $\begin{array}{l}\mathbf{0 . 3 7 5 6 *} \\
0.0000\end{array}$ & $\begin{array}{l}0.2557^{*} \\
0.0011\end{array}$ & $\begin{array}{l}-0.0528 \\
0.5059\end{array}$ & $\begin{array}{l}\mathbf{0 . 4 1 2 2} * \\
0.0000\end{array}$ & 1.0000 & & & \\
\hline $\begin{array}{l}\text { 6. Adoption of environmental } \\
\text { behavior of suppliers }\end{array}$ & $\begin{array}{l}\mathbf{0 . 3 9 7 1} * \\
0.0000\end{array}$ & $\begin{array}{l}0.1919 * \\
0.0147\end{array}$ & $\begin{array}{l}0.1238 \\
0.1178\end{array}$ & $\begin{array}{l}\mathbf{0 . 4 7 8 2} * \\
0.0000\end{array}$ & $\begin{array}{l}0.3021 * \\
0.0001\end{array}$ & 1.0000 & & \\
\hline 7. Innovative capacity & $\begin{array}{l}\mathbf{0 . 3 3 3 6 *} \\
0.0000\end{array}$ & $\begin{array}{l}0.3000 * \\
0.0001\end{array}$ & $\begin{array}{l}0.0567 \\
0.4749\end{array}$ & $\begin{array}{l}\mathbf{0 . 3 0 7 7} * \\
0.0001\end{array}$ & $\begin{array}{l}0.5077 * \\
0.0000\end{array}$ & $\begin{array}{l}0.4283 * \\
0.0000\end{array}$ & 1.0000 & \\
\hline 8. Monitoring of business activities & $\begin{array}{l}\mathbf{0 . 3 8 5 1} * \\
0.0000\end{array}$ & $\begin{array}{l}0.2303 * \\
0.0033\end{array}$ & $\begin{array}{l}-0.0015 \\
0.9854\end{array}$ & $\begin{array}{l}\mathbf{0 . 3 8 0 8} * \\
0.0000\end{array}$ & $\begin{array}{l}0.4558^{*} \\
0.0000\end{array}$ & $\begin{array}{l}0.4052 * \\
0.0000\end{array}$ & $\begin{array}{l}0.4426^{*} \\
0.0000\end{array}$ & 1.0000 \\
\hline
\end{tabular}

(*) $\mathrm{p}<0.05$

\section{Testing For Mediation}

In Step 1, the independent variable, voluntary environmental regulation compliance must influence the dependent variable, the pursuit of competitiveness by developing environmental-friendly products/services. Table 2 below shows the results of the regression analysis describing the relationship between these two variables, while controlling for firm size and sector tangibility. 
Table 2. Step 1 - Relationship Between Voluntary Environmental Regulation Compliance And The Pursuit Of Competitiveness By Developing Environmental-Friendly Products/Services

\begin{tabular}{lc}
\multicolumn{1}{c}{ Variables } & $\begin{array}{c}\text { Pursuit Of Competitiveness By Developing } \\
\text { Environmental-Friendly Products/Services }\end{array}$ \\
\hline Constant & 0.97 \\
Firm size & 0.03 \\
Sector tangibility & 0.17 \\
Voluntary environmental regulation compliance & $0.554^{\mathrm{c}}$ \\
Adjusted $R^{2}$ & $0.258^{\mathrm{c}}$ \\
$F(\mathrm{df} 1, \mathrm{df} 2)$ & 19.56 \\
${ }^{\mathrm{a}} \mathrm{p}<0.1,{ }^{\mathrm{b}} \mathrm{p}<0.05,{ }^{\mathrm{c}} \mathrm{p}<0.001$ &
\end{tabular}

The relationship is significant at the level of 0.001 . The model explains $25.8 \%$ of variance in environmental-based competitiveness $(F=19.56, p<0.001)$. The step 1 is, therefore, supported.

In Step 2, the independent variable, voluntary environmental regulation compliance, must influence the presumed mediator. Table 3 below reports the relationship between voluntary environmental regulation compliance with each of the mediating variables, while controlling for firm size and tangibility of sector.

Table 3. Step 2 - Relationship Between Environmental Regulation Compliance And The Mediating Variables

\begin{tabular}{|c|c|c|c|c|}
\hline Variables & Market Expansion & $\begin{array}{c}\text { Adoption Of } \\
\text { Environmental } \\
\text { Behavior Of Suppliers } \\
\end{array}$ & Innovative Capacity & $\begin{array}{c}\text { Monitoring Of Business } \\
\text { Activities }\end{array}$ \\
\hline Constant & 1.68 & 1.19 & 0.98 & 1.38 \\
\hline Firm size & 0.165 & 0.02 & 0.2 & 0.136 \\
\hline Sector tangibility & -0.735 & 0.106 & 0.01 & -0.02 \\
\hline $\begin{array}{l}\text { Voluntary environmental } \\
\text { regulation compliance }\end{array}$ & $0.42^{c}$ & $0.48^{\mathrm{c}}$ & $0.25^{\mathrm{b}}$ & $0.40^{\mathrm{c}}$ \\
\hline Adjusted $R^{2}$ & $0.18^{\mathrm{c}}$ & $0.23^{\mathrm{c}}$ & $0.127^{\mathrm{c}}$ & $0.16^{\mathrm{c}}$ \\
\hline$F(d f 1, d f 2)$ & 12.74 & 17.26 & 8.74 & 10.03 \\
\hline
\end{tabular}

The relationship with market expansion, adoption of environmental behavior of suppliers, and monitoring of business activities is significant at the level of 0.001. The relationship with innovative capacity is significant at the level of 0.05 . The step 2 is, therefore, supported.

In Step 3, the mediator must influence the dependent variable, pursuit of competitiveness by developing environmental-friendly products/services, while controlling for the independent variable.

Models 1, 2, 3 and 4 in Table 4 report the relationship between the pursuit of competitiveness by developing environmental-friendly products/services and market expansion, adoption of environmental behavior of suppliers, innovative capacity, and monitoring of business activities, respectively. The relationships are all significant at the level of 0.05 . Step 3 is, therefore, supported. 
Table 4. Step 3 - Relationship Between Mediating Variables

And The Dependent Variable While Controlling For The Independent Variable

\begin{tabular}{|c|c|c|c|c|}
\hline \multirow[t]{2}{*}{ Variables } & \multicolumn{4}{|c|}{$\begin{array}{c}\text { Pursuit Of Competitiveness } \\
\text { By Developing Environmental-Friendly Products/Services }\end{array}$} \\
\hline & Model 1 & Model 2 & Model 3 & Model 4 \\
\hline Constant & 1.04 & 0.72 & 0.763 & 0.658 \\
\hline Firm size & 0.011 & 0.026 & -0.012 & -0.002 \\
\hline Sector tangibility & 0.133 & 0.149 & 0.169 & 0.176 \\
\hline $\begin{array}{l}\text { Voluntary environmental } \\
\text { regulation compliance }\end{array}$ & $0.436^{\mathrm{c}}$ & $0.453^{\mathrm{c}}$ & $0.5^{\mathrm{c}}$ & $0.462^{\mathrm{c}}$ \\
\hline Market expansion & $0.157^{\mathrm{b}}$ & & & \\
\hline $\begin{array}{l}\text { Adoption of environmental } \\
\text { behavior of suppliers }\end{array}$ & & $0.211^{\mathrm{b}}$ & & \\
\hline Innovative capacity & & & $0.213^{\mathrm{b}}$ & \\
\hline $\begin{array}{l}\text { Monitoring of business } \\
\text { activities }\end{array}$ & & & & $0.226^{\mathrm{b}}$ \\
\hline Adjusted $R^{2}$ & $0.3^{\mathrm{c}}$ & $0.297^{\mathrm{c}}$ & $0.286^{\mathrm{c}}$ & $0.3^{\mathrm{c}}$ \\
\hline$F(\mathrm{df} 1, \mathrm{df} 2)$ & 18.9 & 16.53 & 17.05 & 18.15 \\
\hline
\end{tabular}

In Step 4, a previously significant relationship between the independent and dependent variables must be reduced in the presence of the mediator. In Table 5 below, models 5, 6, 7, and 8 reports the relationship between voluntary environmental regulation compliance and the pursuit of competitiveness by developing environmentalfriendly products/services, while controlling for market expansion, adoption of environmental behavior of suppliers, innovative capacity, and monitoring of business activities, respectively. The relationship between the two variables is significant at the level of 0.001 and coefficient of 0.554 . It can be seen that with the presence of the mediating variables, this relationship is still significant at the level of 0.001 , but the coefficient is reduced, indicating a weaker relationship. Therefore, step 4 is supported. 
Table 5. Step 4 - Weaker Relationship Between The Independent And Dependent Variables In The Presence Of The Mediator

\begin{tabular}{|c|c|c|c|c|c|}
\hline \multirow{2}{*}{ Variables } & \multicolumn{5}{|c|}{ Pursuit Of Competitiveness By Developing Environmental-Friendly Products/Services } \\
\hline & & Model 5 & Model 6 & Model 7 & Model 8 \\
\hline Constant & 0.97 & 0.6 & 0.987 & 0.76 & 1.00 \\
\hline Firm size & 0.03 & -0.05 & 0.029 & -0.012 & 0.007 \\
\hline Sector tangibility & 0.17 & 0.188 & 0.096 & 0.169 & 0.126 \\
\hline Market expansion & & $0.221^{\mathrm{b}}$ & & & \\
\hline $\begin{array}{l}\text { Adoption of environmental } \\
\text { behavior of suppliers }\end{array}$ & & & $0.248^{\mathrm{b}}$ & & \\
\hline Innovative capacity & & & & $0.213^{\mathrm{b}}$ & \\
\hline $\begin{array}{l}\text { Monitoring of business } \\
\text { activities }\end{array}$ & & & & & $0.207^{\mathrm{b}}$ \\
\hline $\begin{array}{l}\text { Voluntary environmental } \\
\text { regulation compliance }\end{array}$ & $0.554^{\mathrm{c}}$ & $0.46^{\mathrm{c}}$ & $0.395^{\mathrm{c}}$ & $0.5^{\mathrm{c}}$ & $0.426^{\mathrm{c}}$ \\
\hline Adjusted $R^{2}$ & $0.258^{\mathrm{c}}$ & $0.29^{c}$ & $0.33^{c}$ & $0.286^{c}$ & $0.33^{c}$ \\
\hline$F(\mathrm{df} 1, \mathrm{df} 2)$ & 19.56 & 17.71 & 20.72 & 17.05 & 20.99 \\
\hline
\end{tabular}

${ }^{\mathrm{a}} p<0.1,{ }^{\mathrm{b}} p<0.05,{ }^{\mathrm{c}} p<0.001$

\section{DISCUSSION AND CONCLUSION}

We analyzed a sample of 161 French SMEs to examine the relationship between their voluntary compliance to environmental regulation and their motivation to pursue environmental-based competitiveness. We predicted that SMEs are motivated to go further than voluntary regulation compliance to create competitive advantage by developing environmental-friendly products/services because of the following mediators: market expansion, adoption of environmental behavior by their suppliers, innovative capacity, and monitoring of business activities. Results supported all our hypotheses.

Some important insights can be identified based on our findings. First, as presented above, the controversy continues with regard to the ability and motivation of SMEs to go further than mere environmental regulation compliance to create competitiveness based on environmental protection activities. Although scholars tend to agree that environmental regulation is the major push factor of environmental behavior among SMEs, the literature is inconsistent about whether they are pulled by environmental-based competitiveness. Our investigation shows that such inconsistence remains because the mediating variables have been unexplored in the literature. Our study helps contributing to bringing a conclusion to the current debate by revealing the underlying mechanism between the reactive and proactive behavior of environmental practice of SMEs (Bianchi and Noci, 1998; Torugsa, O'Donohue and Hecker, 2013). Our study extends the previous work, which posits the two types of behavior as two ends of a continuum without necessarily having a relationship.

Second, our study takes an important step towards understanding the outcomes of environmental regulation compliance in the context of SMEs. It is commonly heard that SMEs suffer from the uptake of CSR in the business world due to the regulation burden (Williamson et al., 2006) and the pressures for regulation compliance imposed by other actors along the supply chain (Ciliberti et al., 2008). However, our results show that by conforming to the environmental regulations on a voluntary basis, SMEs can expand their market base thanks to the increasing expectation of clients/consumers with regards to environmental behavior of the firm. They can also drive their suppliers to adopt environmental-friendly behavior (Lee and Kim, 2011). Innovative capacity, which has been underlined by Jenkins (2009) as drivers of green products/services development by SMEs, is another consequence of voluntary compliance to environmental regulations. Regulation compliance drives SMEs to monitor better their activities, enabling them to have a better control of their strategic decision making process. They can thereby integrate environmental criteria into their products/services development. These outcomes, in turn, motivate SMEs 
to create environmental-friendly products/services for competitiveness. In short, compliance with environmental regulations not only enables SMEs to respond to external pressure, but also stimulate SMEs to adopt a more proactive behavior in environmental practice. Our study supports the previous studies, which advocates the role of environmental regulations in promoting environmental practice among SMEs (cf. Noci and Verganti, 1999).

Third, the results of our study with regard to the mediating role of clients and suppliers highlight the reciprocal influence between stakeholders of SMEs. Our results confirm the arguments about put forth by the work of Lee and Kim (2011) and Noci and Verganti (1999), which emphasize the role of suppliers in green product innovation development. Our results also support the point of view that consumers can drive SMEs to become environmental-friendly (Albino et al., 2009; Iles, 2008; Lamming and Hampson, 1996). Thus, SMEs can consider creating environmental-based competitiveness by becoming transmitters of environmental requirements in the supply chain (Ayuso et al., 2013).

Our study brings new implications for practice. Due to increased environmental concerns, many SMEs will be progressively faced with the environmental regulations introduced by the government and voluntary standards appreciated by different stakeholders. This study shows that there may be strategic business reasons for the SME owners to consider such changes in the legal environment and voluntary standards as an opportunity to create competitive advantages. 'Win-win' outcomes from environmental practice may indeed be possible. It is even possible to go further and underline the strategic interest to anticipate the evolution of environmental regulations and voluntary environmental standards to create competitive advantages faster than competitors. Overall, our study supports the view that there should be more regulations to control the environmental behavior of businesses (Revell, Stokes, and Chen, 2010).

Our study also has implications for future research. First, although four mediating variables are measured, further research should investigate other mediating processes, such as relationship with the local community or employee engagement. We have revealed the role of SMEs as transmitters of environmental requirements in the supply chain. The factors contributing to a better understanding of SMEs as transmitter of CSR in general deserve attention. Second, with regard to the methodological nature of our work, the investigation is conducted among SME members of the Center for Young Entrepreneurs in France. This may create some bias in their response. Thus, we suggest that the same study should be replicated among other French SMEs and in other countries to generalize our results. Our study is quantitative in nature, relying on an auto-evaluation of the respondents, who are mostly owners/managers of the SMEs. Their responses are dependent upon their understanding of environmental issues and information they have about their firms. This study needs to be complemented by a qualitative study among the most environmental-friendly companies in our sample. This will bring further insights about the relationship between their reactive and proactive behavior of environmental practices. Finally, our investigation was conducted without making distinction between different sectors of activity. It has been acknowledged that the nature of activity sector has an impact on environmental practices of SMEs (Uhlaner et al., 2012). Future study should go into better depth and explore how the influence of the identified mediators varies from one sector to another.

\section{AUTHOR INFORMATION}

Karen Delchet-Cochet is an Associate Professor in Corporate Social Responsibility at ISC Paris since 2010 and is the head of Management and Information Systems Department. She obtained her doctorate degree in Environmental Science at Ecole des Mines de Saint Etienne, France in March 2006. E-mail: karen.delchet-cochet@ iscparis.com

Linh-Chi Vo is an Associate Professor at Normandy Business School. Her research interest includes Corporate Social Responsibility, gender diversity, and innovation. E-mail: linhchivo@gmail.com

Hakim Akeb is an Associate Professor in Computer Science and Data Analysis at ISC Paris Business School since 2007. He obtained his doctorate degree in Computer Science at University of Picardie Jules Verne, Amiens, France in December 2005. E-mail: hakeb@ @iscparis.com (corresponding author) 


\section{REFERENCES}

Adler, P. S., \& Kwon, S. (2002). Social capital: prospects for a new concept. Academy of Management Review, 27(1), $17-40$.

Afsarmanesh, H., \& Camarinha-Matos, L. M. (2009). On the classification and management of virtual organisation breeding environments. International Journal of Information Technology and Management, 8(3), 234-259.

Albino V., Balice, A., \& Dangelico, R. M. (2009). Environmental strategies and green product development: an overview on sustainability-driven companies. Business Strategy and the Environment, 18(2), 83-96.

Ajzen, I. (1991). The theory of planned behavior. Organizational Behavior and Human Decision Processes, 50, $179-211$.

Ambec, S., Cohen, M., Elgie, S., \& Lanoie, P. (2013). The Porter hypothesis at 20: can environmental regulation enhance innovation and competitiveness? Review of Environmental Economics and Policy. 7(1), 2-22.

Antal A. B., Oppen M., \& Sobczak, A. (2009). (Re)discovering the Social Responsibility of Business in Germany. Journal of Business Ethics, 89, 285-301.

Ayuso, S., Roca, M., \& Colome, R. (2013). SMEs as “transmitter" of CSR requirements in the supply chain. Supply Chain Management: an International Journal, 18(5), 497-508.

Baden, D. A., Harwood, I. A., \& Woodward, D. G. (2009). The effect of buyer pressure on suppliers in SMEs to demonstrate CSR practices: An added incentive or counter productive? European Management Journal, 27(6), 429-441.

Baron, R. M., \& Kenny, D. A. (1986). The moderator-mediator variable distinction in social psychological research: conceptual, strategic, and statistical considerations. Journal of Personality and Social Psychology, 51, 11731182.

Barney, J. (1991). Firm resources and sustained competitive advantage. Journal of Management, 17(1), 99-120.

Bhate, S. (2002). One world, one environment, one vision: are we close to achieving this? An exploratory study of consumer environmental behaviour across three countries. Journal of Consumer Behaviour, 2(2), 169-184.

Berchicci, L., \& Bodewes, W. (2005). Bridging environmental issues with new product development. Business Strategy and the Environment, 14, 272-285.

Bianchi, R., \& Noci, G. (1998). Greening SMEs competitiveness. Small Business Economics, 11(3), $269-281$.

Buechler, S. (2000). Social movements in advanced capitalism: the political economy and cultural construction of social activism. New York: Oxford University Press.

Brand, M. J. \& Dam, L. (2009). Corporate Social Responsibility in Small Firms - Illusion or Big Business? Empirical Evidence from the Netherlands, RENT 2009 Conference, Budapest, Hungary.

Brand, U. (2010). Sustainable development and ecological modernization-the limits to a hegemonic policy knowledge. Innovation-The European Journal of Social Science Research, 23(2), 135-152.

Ciliberti, F., Pontrandolfo, P., \& Scozzi, B. (2008). Investigating corporate social responsibility in supply chains: a (sic) SME perspective. Journal of Cleaner Production, 16(15), 1579-1588.

Crowe, D., \& Brennan, L. (2007). Environmental considerations within manufacturing strategy: an international study. Business Strategy and the Environment, 16, 266-289.

Dangelico, R., \& Pujari, D. (2010). Mainstreaming green product innovation: why and how companies integrate environmental sustainability. Journal of Business Ethics, 95(471), 471-486.

Darnall, N., Henriques, I., \& Sadorsky, P. (2008). Do environmental management systems improve business performance in an international setting? Journal of International Management, 14, 364-376.

Delbard, O. (2008). CSR legislation in France and the European regulatory paradox: an analysis of EU CSR policy and sustainability reporting practice. Corporate governance: the international journal of business in society, 8(4), 397-405.

del Brio, J., \& Junquera, B. (2003). A review of the literature on environmental innovation management in SMEs: implications for public policies. Technovation, 23(12), 939-948.

EC. (2001). EU 6th Environmental Action Programme Environment 2010: Our future, our choice. Brussels: European Commission. January 24.

EC. (2003). Communication from the commission: integrated product pol- icy building on life cycle thinking. COM (2003) 302 final. June.

European Commission. (2003). Observatory of European SMEs: Report 2003, SMEs in Europe, Office for Official Publications of the European Communities (Eds.), Luxembourg.

European Multi-Stakeholder Forum. (2004). Report of the round table on fostering CSR among SMEs.

Freeman, R. E. (1984). Strategic Management: A stakeholder approach. Boston: Pitman.

Fuller, T. \& Yumiao, T. (2006). Social and Symbolic Capital and Responsible Entrepreneurship: An Empirical Investigation of SME Narratives. Journal of Business Ethics, 67(3), 287-304.

Gadenne, D., Kennedy, J., \& McKeiver, C. (2009). An empirical study of environmental awareness and practices in 
SMEs. Journal of Business Ethics, 84(1), 45-63.

Geffen, C., Rothenberg, S. (2000). Suppliers and environmental innovation: the automotive paint process. International Journal of Operations and Production Management, 20(2), 166-186.

Gendron C., Lapointe, A., \& Turcotte, M. F. (2004). Responsabilité sociale et régulation de l'entreprise mondialisée. RI/IR, 59(1).

Gombault, M. \& Versteege, S. (1999). Cleaner production in SMEs through a partnership with (local) authorities: successes from the Netherlands. Journal of Cleaner Production, 7(4), 249-261.

Gray, B. (2003). Framing of environmental disputes. In Lewicki, R., Gray, B. and Elliott, M. (Eds.) Making sense of intractable environmental disputes. Washington, DC: Island Press.

Grayson, D., \& Hodges, A. (2004). Corporate Social Opportunity! 7 Steps to Make Corporate Social Responsibility Work for Your Business. Sheffield: Greenleaf.

Howells, J. (2006). Intermediation and the role of intermediaries in innovation. Research Policy, 35(5), $715-728$.

Iles, A. (2008). Shifting to green chemistry: the need for innovations in sustainability marketing. Business Strategy and the Environment, 17(8), 524-535.

Ilomaki, M., \& Melanen, M. (2001). Waste minimisation in small and medium-sized enterprises - do environmental management systems help? Journal of Cleaner Production, 9, 209-217.

Iraldo, F., Testa, F., Melis, M., \& Frey, M. (2011). A literature review on the links between environmental regulation and competitiveness. Environmental Policy and Governance, 21, 210-222.

Jenkins, H. (2006). Small business champions for corporate social responsibility. Journal of Business Ethics, 67, 241-256.

Jenkins, H. (2009). A ‘business opportunity’ model of corporate social responsibility for small-and medium-sized enterprises. Business Ethics: A European Review, 18(1), 21-37.

Klarsfeld, A., Delpueuch, C. (2008). La RSE au-delà de l'opposition entre volontarisme et contrainte : l'apport de la théorie de la régulation sociale et de la théorie néo-institutionnelle. Revue de l'Organisation Responsable, 3(1), 53-64.

Klewitz, J., Zeyen, A., \& Hansen, E. (2012). Intermediaries driving eco-innovation in SMEs: a qualitative investigation. European Journal of Innovation Management, 15(5), 442-467.

Hudson, S., \& Roloff, J. (2010). In search of sustainability? SMEs in Britanny, France. In L. Spence and M. PainterMorland (Eds.), Ethics in small and medium sized enterprises: a global commentary: 193-214. Dordrecht, Netherlands: Springer.

Lamberti, L., \& Noci, G. (2012). The relationship between CSR and corporate strategy in medium-sized companies: evidence from Italy. Business Ethics: A European Review, 21(4), 402-416.

Lamming, R., \& Hampson, J. (1996). The environment as a supply chain issue. British Journal of Management, 7, 45-62.

Lee, K. H. (2009). Why and how to adopt green management into business organizations? Management Decision, 47(7), 1101-1121.

Lee, K. H. \& Kim, J. W. (2011). Integrating suppliers into green product innovation development: an empirical case study in the semiconductor industry. Business Strategy and the Environment, 20, 527-538.

Lepoutre, J. \& Heene, A. (2006). Investigating the impact of firm size on small business social responsibility: A critical review. Journal of Business Ethics, 67, 257-273.

Maloni, M., \& Brown, M. (2006). Corporate social responsibility in the supply chain: an application in the food industry. Journal of Business Ethics, 68, 35-52.

Massa, S., \& Testa, S. (2008). Innovation and SMEs: misaligned perspectives and goals among entrepreneurs, academics, and policy makers. Technovation, 28(7), 393-407.

Mol, A. 2000. The environmental movement in an era of ecological modernization. Geoforum, 31(4), 45-56.

Morrissey, W. J., \& Pittaway, L. (2006). Buyer-supplier relationships in small firms: the use of social factors to manage relationships. International Small Business Journal, 24(3), 272-298.

Noci, G., \& Verganti, R. (1999). Managing Green Product Innovation in Small Firms, R\&D Management, 29(1), 3-15.

Newell, S. J., \& Green, C. L. (1997). Racial differences in consumer environmental concern. The Journal of Consumer Affairs, 31(1), 53-69.

Nidumolu, R., Prahalad, C. K., \& Rangaswami, M. R. (2009). Why sustainability is now the key driver of innovation. Harvard Business Review, 87(9), 56-64.

Ottman, J. A. (1998). Green Marketing: Opportunity for Innovation. NTC: Chicago, IL.

Perrini, F. (2006). SMEs and CSR theory: Evidence and implications from an Italian perspective. Journal of Business Ethics, 67, 305-316.

Perrini, F., \& Minoja, M. (2008). Strategizing corporate social responsibility: evidence from an Italian medium-sized, family-owned company. Business Ethics: A European Review, 17(1), 47-63

Petts, J. (2000). The regulator-regulated relationship and environmental protection: perceptions in small and medium sized enterprises. Environment and Planning: Government and Policy, 21, 549-566.

Porter, M., \& van der Linde, C. (1995). Green and Competitive: Ending the Stalemate. Harvard Business Review, 73(5), 
$120-134$.

Pujari, D., Wright, G., \& Peattie, K. (2003). Green and competitive influences on environmental new product development performance. Journal of Business Research, 56, 657-671.

Putnam, R. (1995). Bowling alone: America's declining social capital. Journal of Democracy, 6(1), 65-78.

Putnam, R. (2000). Bowling Alone: The Collapse and Revival of American Community. New York: Simon and Schuster.

Rege, M. (2000). Strategic policy and environmental quality. Environmental and Resource Economics, 15, $279-296$.

Revell, A., Stokes, D., \& Chen, H. (2010). Small business and the environment: turning over a new leaf?. Business Strategy and the Environment, 19, 273-288.

Roth, J., \& Sheppard, B. (1995). Opening the black box of framing research: the relationship between frames, communication and outcomes. Academy of Management Journal (Best paper proceedings), 94-98.

Rowlands, I. H., Scott, D., \& Parker, P. (2003). Consumers and green electricity: profiling potential purchasers. Business Strategy and the Environment, 12(1), 36-48.

Sharma, S., \& Vredenburg, H. (1998). Proactive corporate environmental strategy and the development of competitively valuable organizational capabilities. Strategic Management Journal, 19(8), 729-753.

Sharma, P., \& Sharma, S. (2011). Drivers of proactive environ- mental strategy in family firms. Business Ethics Quarterly, 21(2), 309-334.

Shrum, L. J., McCarty, J. A., \& Lowrey, T. M. (1995). Buyer characteristics of the green consumer and their implications for advertising strategy. Journal of Advertising, 24(2), 71-82.

Spence, L., Schmidpeter, R., \& Habisch, A. (2003). Assessing social capital: Small and medium sized enterprises in Germany and the UK. Journal of Business Ethics, 47, 17-29.

Sweeney, L. (2007). Corporate social responsibility in Ireland: Barriers and opportunities experienced by SMEs when undertaking CSR. Corporate Governance, 7, 516-523.

Tilley, F. (1999). The Gap Between The Environmental Attitudes and The Environmental Behaviour of Small Firms. Business Strategy and the Environment, 8(4), 238- 248.

Tilley, F. (2000). Small firm environmental ethics: how deep do they go?. Business Ethics: A European Review, 9(1), 31 40.

Tischner, U., Schmincke, E., Rubik, F., \& Prosler, M. (2001). How to Do Ecodesign?: A Guide for Environmentally and Economically Sound Design. Frankfurt: Verlag.

Torugsa, N. A., O’Donohue, W., \& Hecker, R. (2013). Proactive CSR: An Empirical Analysis of the Role of its Economic, Social and Environmental Dimensions on the Association between Capabilities and Performance. Journal of Business Ethics, 115, 383-402.

Tyran, J., \& Engelmann, D. (2005). To buy or not to buy? An experimental study of consumer boycotts in retail markets. Economica, 72(285), 1-16.

Uhlaner, L., Berent-Braun, M., Jeurissen, R. \& de Wit, G. (2010). Family ownership, innovation and other context variables as determinants of sustainable entrepreneurship in SMEs: an empirical research study. EIM research report.

Uhlaner, L., Berent-Braun, M., Jeurissen, R. \& de Wit, G. (2012). Beyond Size: Predicting Engagement in Environmental Management Practices of Dutch SMEs. Journal of Business Ethics, 109, 411-429.

Vives, A. (2006). Social and environmental responsibility in small and medium enterprises in Latin America. Journal of Corporate Citizenship, 21, 39-50.

Wernerfelt, B. (1984). A Resource-Based View of the Firm. Strategic Management Journal, 5(2): 171-180.

Williamson, D., Lynch-Wood, G., \& Ramsay, J. (2006). Drivers of environmental behavior in manufacturing SMEs and the implications for CSR. Journal of Business Ethics, 67, 317-330.

Worthington, I., \& Patton, D. (2005). Strategic intent in the management of green environment within SMEs: an analysis of the UK screen-printing sector. Long Range Planning, 38, 197-212.

Zeng, S., Xie, X., \& Tam, C. (2010). Relationship between cooperation networks and innovation performance of SMEs, Technovation, 30(3), 181-194. 


\section{APPENDIX 1: QUESTIONNAIRE}

Independent variable: voluntary compliance to environmental regulations of voluntary nature

\begin{tabular}{ll}
\hline \multicolumn{1}{c}{ Item } & \multicolumn{1}{c}{ Corresponding question } \\
\hline Carbon release & How is your firm engaged in the reduction of carbon release? \\
\hline Environmental norms and standards & What environmental norms and standards does your firm follow? \\
\hline $\begin{array}{l}\text { Resources for environmental protection } \\
\text { activities }\end{array}$ & $\begin{array}{l}\text { How does your firm provide human and financial resources for } \\
\text { environmental protection activities? }\end{array}$ \\
\hline $\begin{array}{l}\text { Objectives of environmental impact } \\
\text { reduction }\end{array}$ & $\begin{array}{l}\text { How does your firm define objectives in terms of environmental impact } \\
\text { reduction? }\end{array}$ \\
\hline
\end{tabular}

Dependent variable: pursuit of competitiveness by developing environmental-friendly products/services

\begin{tabular}{ll}
\hline \multicolumn{1}{c}{ Item } & \multicolumn{1}{c}{ Corresponding question } \\
\hline $\begin{array}{l}\text { Analysis of the environmental impact of } \\
\text { existing products/services }\end{array}$ & How does your firm analyze the impacts of its activities on the environment? \\
\hline $\begin{array}{l}\text { Development of environmental-friendly } \\
\text { products/services }\end{array}$ & $\begin{array}{l}\text { How does your firm ensure the functional, sanitary, and environmental } \\
\text { quality of your products/services? }\end{array}$ \\
\hline
\end{tabular}

Mediating variables:

\begin{tabular}{ll}
\hline \multicolumn{1}{c}{ Item } & \multicolumn{1}{c}{ Question } \\
\hline Market expansion & $\begin{array}{l}\text { How do you analyze market expectations and the position of your } \\
\text { competitors? }\end{array}$ \\
\hline Analysis of customer expectation & How do you present your offer for prospects/future customers? \\
\hline $\begin{array}{ll}\text { Presentation of products/services to future } \\
\text { customers }\end{array}$ & How does your firm choose your suppliers? \\
\hline Adoption of environmental behavior of suppliers \\
\hline Choice of suppliers & $\begin{array}{l}\text { What social and environmental criteria does your firm impose on your } \\
\text { suppliers? }\end{array}$ \\
\hline Environmental criteria imposed on suppliers & $\begin{array}{l}\text { What kind of suppliers does your firm involve in your projects of } \\
\text { products/services development? }\end{array}$ \\
\hline $\begin{array}{l}\text { Implication of suppliers in environmental } \\
\text { projects }\end{array}$ & $\begin{array}{l}\text { Is there in your enterprise a process of idea creation, selection, and } \\
\text { cultivation? }\end{array}$ \\
\hline Innovative capacity & Is there in your enterprise a process for new idea development and selection? \\
\hline New idea cultivation & $\begin{array}{l}\text { What is the amount of resources allocated to innovation activities and } \\
\text { obtained from the resulting outcomes? }\end{array}$ \\
\hline New idea selection & \\
\hline Measurement of innovative performance & What growth levers do you identify for your enterprise? \\
\hline Monitoring of business activities & How does your firm define its strategy in the medium term (3 to 5 years)? \\
\hline Growth monitoring & $\begin{array}{l}\text { How does your firm stay informed of strategic information related to the } \\
\text { competition? }\end{array}$ \\
\hline Strategic plan &
\end{tabular}


NOTES 